\title{
ENZYMATIC LIPOPHILIZATION OF VITAMIN C WITH LINOLEIC ACID: DETERMINATION OF ANTIOXIDANT AND DIFFUSION PROPERTIES OF L-ASCORBYL LINOLEATE
}

\author{
Marija M. Ćorović ${ }^{1}$, Ana D. Milivojević ${ }^{2}$, Milica B. Carević ${ }^{1}$, Katarina M. Banjanac ${ }^{2}$, \\ Ljubodrag V. Vujisić $^{3}$, Rada V. Pjanović ${ }^{1}$, Dejan I. Bezbradica ${ }^{1}$ \\ ${ }^{1}$ University of Belgrade, Faculty of Technology and Metallurgy, 11000 Belgrade, Karnegijeva 4, Serbia \\ ${ }^{2}$ University of Belgrade, Faculty of Technology and Metallurgy, Innovation Centre, 11000 Belgrade, \\ Karnegijeva 4, Serbia \\ ${ }^{3}$ University of Belgrade, Faculty of Chemistry, 11000 Belgrade, Studentski trg 12, Serbia
}

\author{
${ }^{*}$ Corresponding author: \\ Phone: +381113303724 \\ Fax: +381113370387 \\ E-mail address: mstojanovic@tmf.bg.ac.rs
}

\begin{abstract}
Lipophilic derivatives of vitamin C are additives with antioxidant properties, attractive for application in food, cosmetics and pharmaceutics. They could be synthesized in lipase-catalyzed processes by using various acyl donors. Hereby, we present application of linoleic acid, which is polyunsaturated fatty acid essential in human nutrition, for esterification of vitamin $\mathrm{C}$ catalyzed by immobilized enzyme preparation Novozym ${ }^{\circledR} 435$ in acetone. Highest specific ester yield, $9.7 \mathrm{mmol} / \mathrm{g}$ of immobilized lipase, was accomplished with $0.15 \mathrm{M}$ of vitamin $\mathrm{C}, 0.6 \mathrm{M}$ of linoleic acid, $3 \mathrm{~g} / \mathrm{l}$ of enzyme and $0.07 \%(\mathrm{v} / \mathrm{v})$ of water, at $60{ }^{\circ} \mathrm{C}$. NMR analyses of purified product proved that synthesized molecule was identical to 6-O-ascorbyl linoleate. Capacity of ester for scavenging 2,2-diphenyl-1picrylhydrazyl radicals was two times higher comparing to parent molecule, vitamin $\mathrm{C}$. Its diffusion coefficient, determined using Franz cell and cellulose acetate membrane, was $40 \%$ higher than palmitate and $62 \%$ higher than oleate. Obtained results showed that L-ascorbyl linoleate could be successfully synthesized in biocatalyzed processes. Furthermore, it was demonstrated that it possess high potential for application in different lipophilic products due to its liposolubility, high antioxidant efficiency and good diffusion properties.
\end{abstract}

Key words: vitamin C, lipase, ascorbyl linoleate, antioxidant, diffusivity

\section{INTRODUCTION}

Vitamin $\mathrm{C}$ is natural molecule known for its biological functions and antioxidant properties. However, it is unstable and poorly liposoluble, therefore unsuitable for application in lipophilic products. Products with high lipid content are susceptible to deterioration caused by oxidation of unsaturated fatty acids which they contain. To alter polarity of L-ascorbic acid and improve its stability while saving its beneficial properties, variety of L-ascorbyl fatty acid esters were so far synthesized via esterification and transesterification using sulfuric acid (Cousins et al., 1977; Nickels and Hackenberger, 1986) or lipases as catalysts (Karmee, 2009; Stojanović et al., 2013a). At this moment, L-ascorbyl palmitate and stearate are being commercially produced in chemically catalyzed processes. In recent years, enzymatic pro- 
cesses for the synthesis of valuable products, including fatty acid ascorbyl esters, have attracted attention of researchers, since they are efficient, selective, eco-friendly and, if properly optimized, highly cost-effective.

According to literature data, the most efficient biocatalyst of the process is lipase isoenzyme $\mathrm{B}$ from Candida antarctica (Karmee, 2009; Stojanović et al., 2013a). Liquid enzyme preparations are not adequate for application, due to negative influence of water present in reaction medium on equilibrium position. Immobilized enzymes are almost exclusively applied since they could be easily separated from reaction mixture and reused in repetitive reaction cycles leading to decrease of process costs and increase of commercial competitiveness (Karmee, 2009; MorenoPerez et al., 2013; Stojanović et al., 2013a; Ćorović et al., 2017a; Ćorović et al., 2017b). Different oils, fatty acids and their -methyl, -ethyl, and -vinyl esters were so far used as substrates (Karmee, 2009; Stojanović et al., 2013a; Bezbradica et al., 2017). Saturated fatty acids were predominantly applied, although it is well known fact that unsaturated ones, particularly PUFA-s (polyunsaturated fatty acids) have more beneficial effects on human health. Linoleic acid is unsaturated omega-6 fatty acid with two cis double bonds which is essential for human nutrition. In recent years, ascorbyl linoleate was synthesized enzymatically by several authors (Song et al., 2004; Song et al., 2006; Karmee, 2009). It is proven that linoleic acid reduces inflammation and prevents trans-epidermal moisture loss when applied topically and therefore, it is common ingredient of beauty products (Bradoo et al., 1999; Song and Wei, 2002).

However, just like the other PUFAs, it is prone to autooxidation, which could be prevented by transforming it into ascorbyl ester (Adamczak and Bornscheuer, 2009). Its ascorbyl ester is valuable substance for food, cosmetic, and pharmaceutical industry owing to its nutritional, antioxidant, bleaching, skin conditioning, and skin protecting function (Ando et al., 1992; Song et al. 2004).

The primary purpose of this study was to synthesize L-ascorbyl linoleate using immobilized Candida antarctica lipase $\mathrm{B}$ as a catalyst (Scheme 1.), to purify it, and to characterize it in terms of antioxidant and diffusion properties.

First part of the research was focused on the optimization of essential esterification parameters - limiting substrate concentration, substrates molar ratio, water content, and enzyme amount in order to maximize conversion degrees and ester yields. Afterwards, product was isolated and its structure was confirmed by NMR. Purified ascorbyl linoleate was further used for determination of its free radical scavenging capacity. Diffusion coefficient of synthesized molecule was determined, as well.<smiles>CCCCC/C=C/C/C=C/CCCCCCCC(=O)OCC(O)C1OC(=O)C(O)=C1O</smiles>

Scheme 1. Lipase-catalyzed esterification of vitamin C with linoleic acid 


\section{MATERIALS AND METHODS}

Lipase B from Candida antarctica immobilized onto acrylic resin, Novozym ${ }^{\circledR} 435$, was obtained from Novozymes (Bagsvaerd, Denmark). All reactions were performed by using L-ascorbic acid (99.7\%, Zorka, Šabac, Serbia) and linoleic acid $(\geq 99 \%$, Sigma-Aldrich Chemie Gmbh, Steinheim, Germany), oleic acid (85\%, TCl Europe, Zwijndrecht, Belgium) or stearic acid (98\%, Sigma-Aldrich Chemie Gmbh, Steinheim, Germany) as substrates and acetone (p.a., AppliChem, Darmstadt, Germany) as a solvent. HPLC analyses were conducted with methanol purchased from JT Baker, USA, and formic acid obtained from Sigma-Aldrich Chemie Gmbh, Steinheim, Germany, both of HPLC grade. 2,2-Diphenyl-1-picryl-hydrazyl radical (DPPH) and ascorbyl palmitate $(\geq 99 \%)$ were purchased from Sigma-Aldrich Chemie Gmbh, Steinheim, Germany, as well. Acetate cellulose membrane filters $(0.2 \mu \mathrm{m}$ pore size, $47 \mathrm{~mm}$ diameter), used for diffusion study were obtained from Whatman (Dassel, Germany).

\section{Procedure for ester synthesis}

Esterification reactions were conducted in $100 \mathrm{ml}$ sealed Erlenmeyer flasks, in thermostated orbital shaker at $60{ }^{\circ} \mathrm{C}$ and 200 rpm for $72 \mathrm{~h}$. Reaction mixtures consisted of vitamin C, linoleic acid and water (amounts defined for each experiment individually), while organic solvent - acetone was added to reach the final volume of 10 $\mathrm{ml}$. Reactions were initiated by adding predefined amounts of biocatalyst, while control samples did not contain immobilized lipase and were exposed to same treatment as all other samples. All experiments were conducted in duplicates and average values are presented in graphs. Deviations were less than $5 \%$.

\section{HPLC analyses}

Quantitative analyses of reactants and products were performed by HPLC on Dionex Ultimate 3000 Thermo Scientific (Waltham, USA) system and a reverse phase column (Hypersil GOLD C18, 150 $\mathrm{mm} \times 4.6 \mathrm{~mm}, 5 \mu \mathrm{m})$. During reaction, 50 $\mu l$ of reaction mixtures were withdrawn for quantitative analyses. Reaction mixture samples were diluted 50-100 times with methanol before analyses. Injection volumes were $15 \mu \mathrm{l}$. As a mobile phase, methanol/formic acid, 100/0.1\% (v/v) with a flow rate of $0.5 \mathrm{ml} / \mathrm{min}$, was used. UV-VIS detector was used and ester was detected at $235 \mathrm{~nm}$.

\section{Purification of product}

Reaction mixture was filtered, evaporated under vacuum, diluted 10 times comparing to initial mixture and subjected to HPLC system with fraction collector. Semipreparative reverse-phase column (Hypersil Gold ODS, $250 \mathrm{~mm} \times 10 \mathrm{~mm}, 5 \mu \mathrm{m}$, Thermo Fisher Scientific, Waltham, USA) was used. Mobile phase used for preconditioning of column and elution was acetonitrile/water $95 / 5 \%(\mathrm{v} / \mathrm{v})$ with $0.1 \%$ of formic acid. Elution flow rate was $6 \mathrm{ml} / \mathrm{min}$ and injection volume of samples was $1 \mathrm{ml}$. Fractions of pure product were collected in portions of $0.5 \mathrm{ml}$, retested on analytical column and evaporated to constant weight. Detection was done at $235 \mathrm{~nm}$.

\section{Spectral analyses}

NMR spectrums were obtained on Varian Gemini $200\left({ }^{1} \mathrm{H}\right.$ NMR at $200 \mathrm{MHz},{ }^{13} \mathrm{C}$ $\mathrm{NMR}$ at $50 \mathrm{MHz}$ ) instrument (Varian Medical Systems, Palo Alto, USA). Chemical shifts were expressed as ppm (parts per million) using 2,2-dimethyl-2-silapentane5 -sulfonate sodium salt as an internal standard.

\section{Antioxidant activity determination}

Antioxidant activity of L-ascorbyl linoleate was measured spectrophotometrically by standard DPPH (2,2-diphenyl-1-picrylhydrazyl) method based on ability of tested compounds to act as electron acceptors and to reduce stable DPPH radical (Sharma and Bhat, 2009). Reaction mixture consisted of $200 \mu \mathrm{l}$ of analyzed sample with concentration of $0-5 \mathrm{mg} / \mathrm{ml}$ of ester, $200 \mu \mathrm{l}$ of $0.15 \mathrm{mM}$ DPPH solution in methanol and $600 \mu \mathrm{l}$ of pure methanol. Control samples were composed from 800 $\mu \mathrm{l}$ of methanol and $200 \mu \mathrm{l}$ of DPPH solution. Mixtures were vortexed for $2 \mathrm{mi}-$ nutes and left for 30 minutes at room 
temperature in the dark. Absorbance was measured afterwards at $517 \mathrm{~nm}$, and free radical scavenging capacity (FRSC) was calculated as follows:

$\operatorname{FRSC}(\%)=\frac{\left(A_{C}-A_{S}\right)}{A_{c}} \cdot 100$

Where $A_{c}$ is absorbance of control sample and $A_{s}$ is absorbance of analyzed sample. Final result was expressed $\mathrm{IC}_{50}$ (half minimal inhibitory concentration) value which represents concentration of antioxidant which lowers initial concentration of DPPH radicals by $50 \%$.

\section{Diffusion studies}

Diffusion studies were conducted in jacketed Franz diffusion cell (PermeGear, Inc., Hellertown, PA, USA) made of two compartments separated with acetatecellulose membrane (pore size of $0.2 \mu \mathrm{m}$ ).

As samples, placed in the donor compartment, approximately $2 \mathrm{~g}$ of reaction mixtures free of catalyst and solvent (removed by vacuum evaporation) were used.

The receptor compartment was filled with medium (50\% ethyl alcohol) and continuously stirred at $400 \mathrm{rpm}$ using magnetic bead (Klimundová et al., 2006). The samples were taken in appropriate time intervals during $24 \mathrm{~h}$ from receptor chamber and subjected to HPLC analyses for determination of ascorbyl ester concentrations.

The diffusion coefficients were calculated using Fick's second law, as described by Pjanović et al. (Pjanović et al., 2010):

$D=-\frac{1}{\beta \cdot t} \ln \left(\frac{C_{D}-C_{R}}{C_{D}^{0}-C_{R}^{0}}\right)$

and its linearized form

$\ln \left(\frac{C_{D}^{0}-C_{R}^{0}}{C_{D}-C_{R}}\right)=D \cdot \beta \cdot t$

Where $\beta\left(24900 \mathrm{~min} / \mathrm{m}^{2}\right)$ is geometric constant related to a cell type, $t(\mathrm{~min})$ is time, $C(\mathrm{~g} / \mathrm{l})$ is concentration, subscripts $R$ and $D$ refer to receptor and donor compartment, respectively, and super- script 0 refers to initial conditions (at zero time).

\section{RESULTS AND DISCUSSION}

\section{Optimization of reaction conditions}

Lipase catalyzed esterifications are reversible reactions, strongly affected by several experimental factors - substrates concentration, water content and concentration of biocatalyst. Hence, it is of great importance to optimize all parameters influencing equilibrium yield of ester, as well as duration and costs of biosynthesis process.

At the beginning of the study, concentrations of both reactants were varied within wide ranges, with the aim of their optimization. At first, concentration of acyl acceptor - L-ascorbic acid was kept constant, while influence of linoleic acid concentration on esterification progress was examined. In previous studies, different substrate molar ratios were established as optimal (Karmee, 2009; Stojanović et al., 2013a; Bezbradica et al., 2017).

In general, excessive amount of acyl donor was used in order to alter the equilibrium of reaction toward the esterification (Park et al., 2003; Burham et al., 2009; Stojanović et al., 2013b). In this research, substrates molar ratio was varied from 1:1 to $1: 10$ (Fig. 1).

It can be noticed that increase of molar ratio up to $1: 4$ led to higher conversions (after $48 \mathrm{~h}$ maximum conversion of $27.3 \%$ was achieved).

Further increase caused steep decrease in accomplished conversions. This is in accordance with some previous reports, and it was probably due to diffusion limitation induced by linoleic acid high viscosity and/or reduced solubility of vitamin $C$ in reaction medium with higher $\log P$ value (Burham et al., 2009).

Furthermore, influence of limiting substrate concentration on both conversion degree and product yield was investigated. Lascorbic acid concentration was varied from 0.05 to $0.2 \mathrm{M}$ and obtained results are depicted in Figs. $2 a$ and $2 b$. 


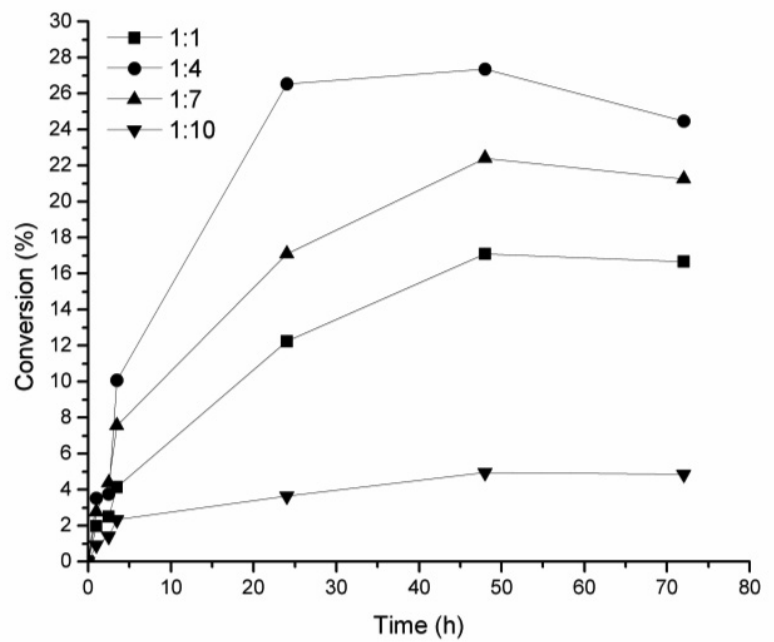

Figure 1. Influence of substrate molar ratio on molar conversion. Experiments were conducted with $0.15 \mathrm{M}$ of vitamin C, $5 \mathrm{~g} / \mathrm{l}$ of lipase, and $0.07 \%(\mathrm{v} / \mathrm{v})$ of water

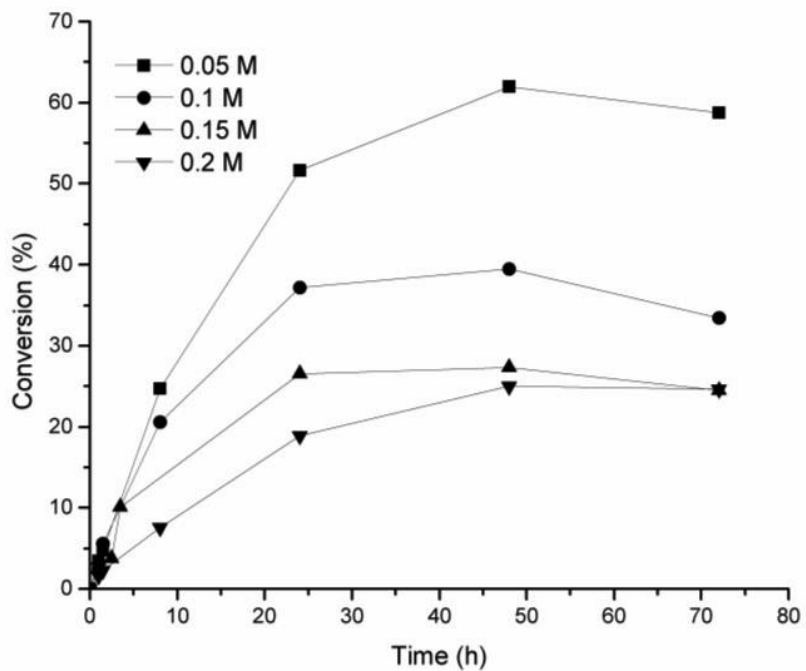

a)

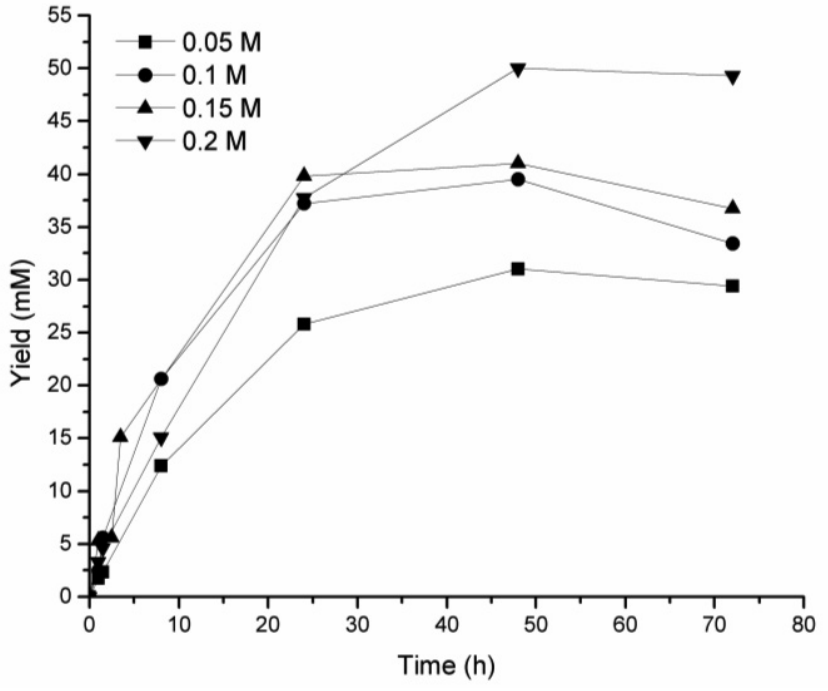

b)

Figure 2. Influence of vitamin C concentration on molar conversion (a) and product yield (b). Experiments were conducted at 1:4 substrate molar ratio, $5 \mathrm{~g} / \mathrm{l}$ of lipase, and $0.07 \%(\mathrm{v} / \mathrm{v})$ of water 


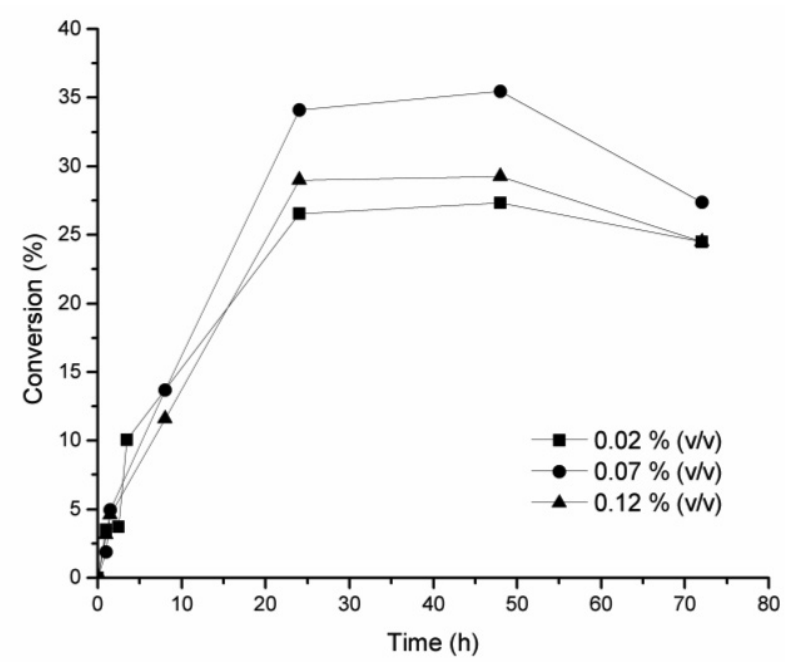

Figure 3. Influence of initial water content on molar conversion. Experiments were conducted at 1:4 substrate molar ratio, $5 \mathrm{~g} / \mathrm{l}$ of lipase, and $0.15 \mathrm{M}$ of vitamin $\mathrm{C}$

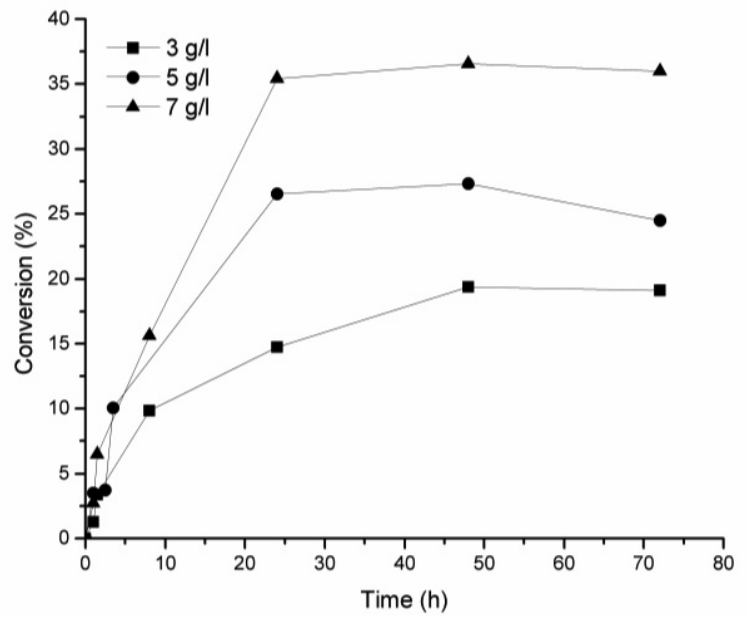

a)

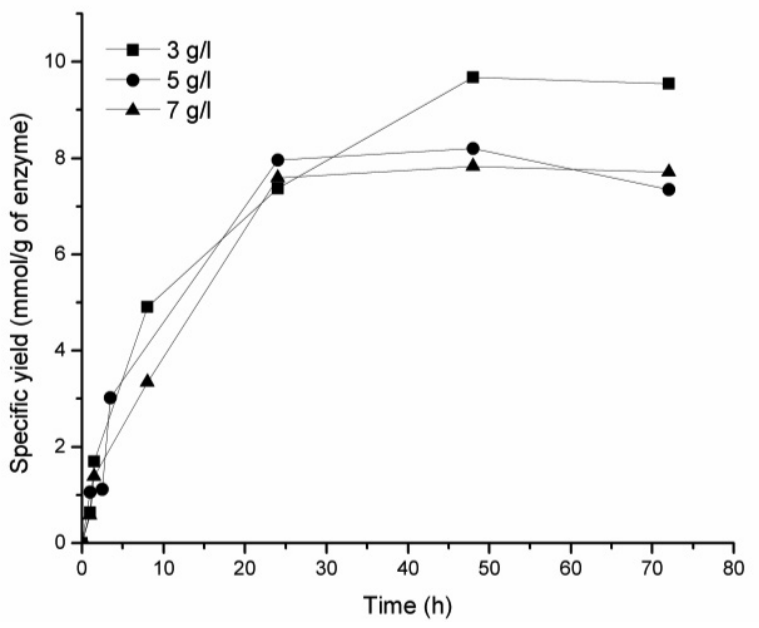

b)

Figure 4. Influence of lipase loading on molar conversion (a) and specific yield (b). Experiments were conducted at $1: 4$ substrate molar ratio, $0.07 \%(\mathrm{v} / \mathrm{v})$ of water, and $0.15 \mathrm{M}$ of vitamin $\mathrm{C}$

In Fig. $2 a$ it is presented that highest conversion $(62.0 \%)$ was obtained at lowest concentration of vitamin $\mathrm{C}(0.05 \mathrm{M})$, while the same reaction parameter sho- wed opposite effect on yield of ester (maximum of $50.0 \mathrm{mM}$ of ascorbyl linoleate was synthesized at $0.2 \mathrm{M}$ of vitamin $C)$, as it is evident from figure $2 b$. This 
result is similar to one obtained by Song and coworkers, who reached conversion degree of $21.8 \%$ at $0.3 \mathrm{M}$ limiting substrate concentration (Song et al., 2006). These yields could be increased to some extent by using more expensive acyl donor (methyl linoleate) (Song et al., 2006) or solvent (ionic liquid) (Chen et al., 2008) which would lead to significant increase of overall process costs. Several authors previously reported positive effect of two double bonds present in hydrocarbon chain of linoleic acid on achieved conversion degrees in lipase-catalyzed ascorbic acid esterification reactions, in comparison to other $\mathrm{C} 18$ fatty acids, monounsaturated oleic acid and saturated stearic acid, (Song et al., 2004). Therefore, linoleic acid could be regarded as adequate acyl donor for the production of vitamin $\mathrm{C}$ based lipophilic antioxidant.

Side product of esterification reaction between linoleic acid and vitamin $C$ is water. Therefore, high water content in medium is undesirable for position of reaction equilibrium (Stojanović et al., 2013b).

On the other hand, lipases are known to keep their active conformation only if they are surrounded by monomolecular layer of water (Hsieh et al., 2005). In accordance with that, initial water content was optimized (varied in range 0.02-0.12\% $(\mathrm{v} / \mathrm{v}))$ and influence of this parameter on reaction progress was monitored. Highest conversion was achieved at $0.07 \%(\mathrm{v} / \mathrm{v})$ of water (Fig.3). Although some previous researches implied that Novozym ${ }^{\circledR} 435$ contains sufficient amount of water for preservation of its catalytic activity (Salis et al., 2005; Tamalampudi et al., 2008), our study showed that some water in the reaction mixture had positive effect.
Finally, loading of the immobilized lipase was optimized. Concentrations of the catalyst from 3-7 g/l were examined. It has been shown (Fig. 4a) that an increase in lipase loading has positive effect on limiting substrate molar conversion.

However, price of the enzyme is the greatest of all expenses of the process and therefore, its consumption should be minimized.

Hence, yield of the product per mass of lipase (specific yield) was also taken into consideration. As it can be seen in Fig. 4b, maximum specific yield of $9.7 \mathrm{mmol}$ of ester per gram of lipase was accomplished at lowest enzyme concen-tration - $3 \mathrm{~g} / \mathrm{l}$.

\section{Spectral analyses}

L-ascorbyl linoleate synthesized under optimized conditions $(0.15 \mathrm{M}$ vitamin $\mathrm{C}$, $1: 4$ molar ratio, $0.07 \%(\mathrm{v} / \mathrm{v})$ of water and 3 $\mathrm{g} / \mathrm{l}$ of enzyme) was collected as a pure substance using semipreparative RPHPLC and subjected to spectral analyses.

Following NMR spectrum was determined: ${ }^{1} \mathrm{H}$ NMR $\left(200 \mathrm{MHz}, \mathrm{CDCl}_{3}\right) \delta 4.79(\mathrm{H}-4$, $1 \mathrm{H}), \delta 4.35(\mathrm{H}-5,1 \mathrm{H}), \delta 4.23(\mathrm{H}-6,2 \mathrm{H}), \delta$ $5.34\left(\mathrm{H}^{-9}, \mathrm{H}-10^{\prime}, \mathrm{H}-12^{\prime}\right.$ and $\left.\mathrm{H}-13^{\prime}, 4 \mathrm{H}\right)$, $\delta$ $2.77\left(\mathrm{H}-11^{\prime}, 2 \mathrm{H}\right), \delta 2.35\left(\mathrm{H}-2{ }^{\prime}, 2 \mathrm{H}\right), \delta 2.03$ $\left(\mathrm{H}-8^{\prime}\right.$ and $\left.\mathrm{H}^{-14} \mathbf{4}^{\prime}, 4 \mathrm{H}\right), \delta 1.61\left(\mathrm{H}^{-17}, 2 \mathrm{H}\right), \delta$ $1.3\left(\mathrm{H}-3^{\prime}-\mathrm{H}^{-} 7^{\prime}, \mathrm{H}-15^{\prime}\right.$ and $\left.\mathrm{H}-16^{\prime}, 14 \mathrm{H}\right), \delta$ $0.89(\mathrm{H}-18,3 \mathrm{H})$.

Presence of characteristic functional groups was confirmed, as well: C13 NMR $\left(50 \mathrm{MHz}, \mathrm{CDCl}_{3}\right)$ - CO-O (ester) 172.73 ppm; CO (carbonyl) $174.21 \mathrm{ppm}$; enolic C $153.6 \mathrm{ppm}$ and $118.53 \mathrm{ppm} ; \mathrm{CH}=\mathrm{CH}$ $130.22 \mathrm{ppm}$ and $127.87 \mathrm{ppm}$. In this way, it was proven that isolated substance was 6-O-ascorbyl linoleate.

Table 1.

DPPH radical scavenging capacity of fatty acid ascorbyl esters

\begin{tabular}{cccccc}
\hline Compound & $\begin{array}{c}\text { L-ascorbic } \\
\text { acid }\end{array}$ & $\begin{array}{c}\text { L-ascorbyl } \\
\text { linoleate }\end{array}$ & $\begin{array}{c}\text { L-ascorbyl } \\
\text { oleate }\end{array}$ & $\begin{array}{c}\text { L-ascorbyl } \\
\text { stearate }\end{array}$ & $\begin{array}{c}\text { L-ascorbyl } \\
\text { palmitate }\end{array}$ \\
\hline $\mathrm{IC}_{50}, \boldsymbol{\mu M}$ & 0.81 & 0.45 & 0.65 & 1.75 & 1.55 \\
\hline
\end{tabular}

Table 2

Diffusion coefficients of fatty acid ascorbyl esters

\begin{tabular}{cccc}
\hline Compound & L-asocrbyl linoleate & L-ascorbyl palmitate & L-ascorbyl oleate \\
\hline $\mathbf{D} \times 10^{9}, \mathrm{~m}^{2} / \mathrm{min}$ & 3.45 & 2.49 & 2.13 \\
\hline
\end{tabular}




\section{DPPH analyses}

Primary function of L-ascorbyl linoleate is to prevent deterioration of lipids in oils and emulsions.

To prove that antioxidant properties of vitamin $\mathrm{C}$ are preserved after its esterification with linoleic acid, standard method which determines capacity of compound for scavenging DPPH radical was employed and obtained result is expressed as its $\mathrm{IC}_{50}$ value.

As it can be observed from Table $1, I_{50}$ value (in $\mu \mathrm{M}$ ) of L-ascorbyl linoleate was $0.45 \mu \mathrm{M}$ - approximately 2 times lower in comparison to pure vitamin $\mathrm{C}$, which indicated that by acylating it, more potent antioxidant could be gained. This result is not unexpected, since it has been previously reported that some fatty acid ascorbyl esters possess higher capacity for scavenging of several free radical species than their parent molecule, vitamin C (Liu et al., 2011). Ascorbyl linoleate demonstrated higher antioxidant capacity comparing to ascorbyl stearate and oleate, which were synthesized and characterized within our previous publication (Stojanovic et al., 2015). There appears to be a trend towards increasing free radical scavenging activity with increasing FAAE acyl residue unsaturation degree that additionally recommends the application of PUFAs as acyl donors for lipase-catalyzed production of ascorbyl esters. Moreover, DPPH radical scavenging capacity of L-ascorbyl linoleate was more than three times higher comparing to commercially available L-ascorbyl palmitate.

\section{Diffusion properties}

Fatty acid ascorbyl esters are already introduced into cosmetic industry as bioactive ingredients with remained antioxidant, antiaging and skin-lightening properties of vitamin C (Andersen, 1999; Špiclin et al., 2001). In order to investigate potential of synthesized L-ascorbyl linoleate for application in topical formulations and compare its diffusion coefficient with commercial palmitate and synthesized oleate and stearate, diffusion experiments in Franz cell were conducted. Based on results presented in Table 2., it could be noticed that diffusion coefficient of linoleate was $40 \%$ higher than palmitate and $62 \%$ higher than oleate, while stearate was not detected in samples taken from receptor compartment within all 24 hours.

Such behavior is most likely caused by multiple factor effect, including solubility, molecular weight, log $P$, etc. Obtained results indicate that $L$-ascorbyl linoleate is a promising molecule for cosmetic formulations with the function of delivering active substance into deeper skin layers. For its final characterization, experiments with human skin model membranes are still to be performed in the future. Also, different dermocosmetic preparations should be tested since stability and diffusion properties of fatty acid ascorbyl esters are dependent on formulation structural properties (Austria et al., 1997).

\section{CONCLUSIONS}

Main goals of this research were examination of the influence of key experimental factors on lipase-catalyzed synthesis of ascorbyl linoleate in acetone, product purification, structural characterization and determination of its antioxidant and diffusion properties. Obtained results are comparable to those achieved by other authors with more expensive solvents and/or activated acyl donors and hence, could be used in further optimization studies or in investigations on larger scale. Moreover, determined antioxidant capacity and diffusion coefficient recommend L-ascorbyl linoleate for application in food, cosmetics and pharmaceutics.

\section{ACKNOWLEDGEMENTS}

The authors are grateful for financial support from the Serbian Ministry of Education, Science and Technological Development (project III 46010).

\section{REFERENCES}

1. Adamczak, M., Bornscheuer, U.T. (2009). Improving ascorbyl oleate synthesis catalyzed by Candida antarctica lipase B in ionic liquids and water activity control by salt hydrates. Process Biochemistry, 44 (3), 257-261.

2. Andersen, F.A. (1999). Final report on the safety assessment of ascorbyl palmitate, as- 
corbyl dipalmitate, ascorbyl stearate, erythorbic acid, and sodium erythorbate. International Journal of Toxicology, 18 (SUPPL. 3), 1-26.

3. Ando, H., Shimizu, M., Hashimoto, A., Kato, H., Ozasa, Y. (1992). Skin whitening cosmetics. U.S. Patent No. 5,078,989. U.S. Patent and Trademark Office, Washington, DC.

4. Austria, R., Semenzato, A., Bettero, A. (1997). Stability of vitamin $C$ derivatives in solution and topical formulations. Journal of Pharmaceutical and Biomedical Analysis, 15 (6), 795-801.

5. Bezbradica, D., Ćrovic, M., Tanasković, S. J., Luković, N., Carević, M., Milivojević, A., Knezević-Jugović, Z. (2017). Enzymatic syntheses of esters - Green chemistry for valuable food, fuel and fine chemicals. Current Organic Chemistry, 21 (2), 104-138.

6. Bradoo, S., Saxena, R.K., Gupta, R. (1999). High yields of ascorbyl palmitate by thermostable lipase-mediated esterification. JAOCS, Journal of the American Oil Chemists' Society, 76 (11), 1291-1295.

7. Burham, H., Rasheed, R.A. G.A., Noor, N. M., Badruddin, S., Sidek, H. (2009). Enzymatic synthesis of palm-based ascorbyl esters. Journal of Molecular Catalysis B: Enzymatic, 58 (1-4), 153-157.

8. Chen, B., Guo, Z., Let, M. B., Lue, B.-M., Xu, X. (2008). Preparation of CLA ascorbyl ester with improved volumetric productivity by an ionic liquid-based reaction system. Organic and Biomolecular Chemistry, 6 (17), 3196-3201.

9. Ćorović, M., Mihailović, M., Banjanac, K., Carević, M., Milivojević, A., Milosavić, N., Bezbradica, D. (2017). Immobilization of Candida antarctica lipase B onto Purolite $\AA$ MN102 and its application in solvent-free and organic media esterification. Bioprocess and Biosystems Engineering, 40 (1), 23-34.

10. Ćorović, M., Milivojević, A., Carević, M., Banjanac, K., Jakovetić Tanasković, S., Bezbradica, D. (2017). Batch and semicontinuous production of L-ascorbyl oleate catalyzed by CALB immobilized onto Purolite ${ }^{\circledR}$ MN102. Chemical Engineering Research and Design, 126, 161-171.

11. Cousins, R.C., Seib, P.A., Hoseney, R.C., Deyoe, C.W., Liang, Y. T., Lillard, D. W. (1977). Synthesis of 6-fatty acid esters of I-ascorbic acid. Journal of the American Oil Chemists' Society, 54 (8), 308-312.

12. Hsieh, H.J., Chen, J. W., Giridhar, R., Wu, W. T. (2005). Synthesis of mixed esters of ascorbic acid using methyl esters of palm and soybean oils. Preparative Biochemistry and Biotechnology, 35 (2), 113-118.

13. Karmee, S.K. (2009). Biocatalytic synthesis of ascorbyl esters and their biotechnological applications. Applied Microbiology and Biotechnology, 81 (6), 1013-1022.

14. Klimundová, J., Šatinský, D., Sklenářová, H., Solich, P. (2006). Automation of simultaneous release tests of two substances by sequential injection chromatography coupled with Franz cell. Talanta, 69 (3), 730-735.
15. Liu, Y., Wang, J., Yan, Y., Li, J. (2011). Biocatalytic synthesis and antioxidant capacities of ascorbyl esters by Novozym 435 in tert-butanol system using different acyl donors. African Journal of Biotechnology, 10 (75), 1728217290.

16. Moreno-Perez, S., Filice, M., Guisan, J.M., Fernandez-Lorente, G. (2013). Synthesis of ascorbyl oleate by transesterification of olive oil with ascorbic acid in polar organic media catalyzed by immobilized lipases. Chemistry and Physics of Lipids, 174, 48-54.

17. Nickels, H.D., Hackenberger, A.D. (1987). Process for producing fatty acid esters of ascorbic acid. U.S. Patent No. 4,705,869. U.S. Patent and Trademark Office, Washington, DC.

18. Park, S., Viklund, F., Hult, K., Kazlauskas, R. J. (2003). Vacuum-driven lipase-catalysed direct condensation of L-ascorbic acid and fatty acids in ionic liquids: Synthesis of a natural surface active antioxidant. Green Chemistry, 5 (6), 715719.

19. Pjanović, R., Bošković-Vragolović, N., Veljković Giga, J., Garić-Grulović, R., Pejanović, S., Bugarski, B. (2010). Diffusion of drugs from hydrogels and liposomes as drug carriers. Journal of Chemical Technology and Biotechnology, 85 (5), 693-698.

20. Salis, A., Pinna, M., Monduzzi, M., Solinas, V. (2005). Biodiesel production from triolein and short chain alcohols through biocatalysis. Journal of Biotechnology, 119 (3), 291-299.

21. Sharma, O.P., Bhat, T.K. (2009). DPPH antioxidant assay revisited. Food Chemistry, 113 (4), 1202-1205.

22. Song, Q.-X., Wei, D.-Z., Zhou, W.-Y., Xu, W.Q., Yang, S.-L. (2004). Enzymatic synthesis and antioxidant properties of L-ascorbyl oleate and L-ascorbyl linoleate. Biotechnology Letters, 26 (23), 1777-1780.

23. Song, Q., Zhao, Y., Xu, W., Zhou, W., Wei, D. (2006). Enzymatic synthesis of L-ascorbyl linoleate in organic media. Bioprocess and Biosystems Engineering, 28 (4), 211-215.

24. Song, Q. X., Wei, D. Z. (2002). Study of Vitamin $C$ ester synthesis by immobilized lipase from Candida sp. Journal of Molecular Catalysis B: Enzymatic, 18 (4-6), 261-266.

25. Špiclin, P., Gašperlin, M., Kmetec, V. (2001). Stability of ascorbyl palmitate in topical microemulsions. International Journal of Pharmaceutics, 222 (2), 271-279.

26. Stojanovic, M., Carevic, M., Mihailovic, M., Veličkovic, D., Dimitrijevic, A., Milosavic, N., Bezbradica, D. (2015). Influence of fatty acid on lipase-catalyzed synthesis of ascorbyl esters and their free radical scavenging capacity. Biotechnology and Applied Biochemistry, 62 (4), 458-466.

27. Stojanović, M., Veličković, D., Dimitrijević, A., Milosavić, N., Knežević-Jugović, Z., Bezbradica, D. (2013b). Lipase-catalyzed synthesis of ascorbyl oleate in acetone: Optimization of reaction conditions and lipase reusability. Journal of Oleo Science, 62 (8), 591-603. 
28. Stojanović, M. M., Carević, M. B., Mihailović, M. D., Knežević-Jugović, Z.D., Petrović, S.D., Bezbradica, D. I. (2013a). Enzymatic synthesis and application of fatty acid ascorbyl esters. Hemijska Industrija, 67 (2), 239-247.

29. Tamalampudi, S., Talukder, M. R., Hama, S.,
Numata, T., Kondo, A., Fukuda, H. (2008).

30. Enzymatic production of biodiesel from Jatropha oil: a comparative study of immobilizedwhole cell and commercial lipases as a biocatalyst. Biochemical Engineering Journal, 39 (1), 185-189.

\title{
ЕНЗИМСКА ЛИПОФИЛИЗАЦИЈА ВИТАМИНА Ц ЛИНОЛНОМ КИСЕЛИНОМ: ОДРЕЂИВАЊЕ АНТИОКСИДАТИВНИХ И ДИФУЗИОНИХ СВОЈСТАВА L-АСКОРБИЛ-ЛИНОЛАТА
}

\author{
Марија М. Ћоровић*1, Ана Д. Миливојевић ${ }^{2}$, Милица Б. Царевић ${ }^{1}$, Катарина М. \\ Бањанац ${ }^{2}$, Љубодраг В. Вујисић ${ }^{3}$, Рада В. Пјановић ${ }^{1}$, Дејан И. Безбрадица ${ }^{1}$ \\ ${ }^{1}$ Универзитет у Београду, Технолошко-металуршки фракултет, 11000 Београд, \\ Карнегијева 4, Србија \\ ${ }^{2}$ Универзитет у Београду, Технолошко-металуршки фракултет, Иновациони центар, \\ 11000 Београд, Карнегијева 4, Србија \\ ${ }^{3}$ Универзитет у Београду, Хемијски фракултет, 11000 Београд, Студентски трг 12, Србија
}

Сажетак: Липофилни деривати витамина Ц су адитиви са антиоксидативним дејством погодни за примену у прехрамбеним, козметичким и фрармацеутским производима. Могу бити синтетисани у процесима катализованим липазама коришћењем различитих ацил-донора. У овом раду, описана је примена линолне киселине, полинезасићене масне киселине есенцијалне у људској исхрани, у естерификацији витамина Ц катализованој имобилисаним ензимским препаратом Novozym ${ }^{\circledR} 435$ у ацетону. Највиши специфични принос естра од $9,7 \mathrm{mmol} / \mathrm{g}$ имобилисане липазе, остварен је са 0,15 М витамина Ц, 0,6 М линолне киселине, 3 g/l ензима и 0,07 запр. \% воде, на $60{ }^{\circ} \mathrm{C}$. NMR анализе пречишћеног производа доказале су да је синтетисани молекул идентичан 6-О-аскорбил-линолату. Капацитет естра за везивање 2,2дифенил-1-пикрилхидразил радикала био је два пута виши у односу на сам витамин Ц. Његов коефицијент дифузије, одређен коришћењем Franz-ове ћелије и целулоза-ацетатне мембране, био је за $40 \%$ виши у односу на палмитат и за $62 \%$ у односу на олеат. Остварени резултати показали су да L-аскорбил-линолат може успешно бити синтетисан у биокатализованом процесу. Поред тога, доказано је да овај естар поседује значајан потенцијал за примену у различитим липофилним производима због своје липосолубилности, снажног антиоксидативног дејства и погодних дифузионих карактеристика.

Кључне речи: витамин Ц, липаза, аскорбил линолат, антиоксиданс, дифузивност

Received: 4 May 2018

Received in revised form: 1 June 2018

Accepted: 6 June 2018 